\title{
Wnt Inhibitory Factor 1
}

National Cancer Institute

\section{Source}

National Cancer Institute. Wht Inhibitory Factor 1. NCI Thesaurus. Code C97869.

Wnt inhibitory factor 1 (379 aa, $\sim 42 \mathrm{kDa}$ ) is encoded by the human WIF1 gene. This protein plays a role in the negative regulation of Wnt signaling. 